\title{
SPATIAL CONCENTRATION OF INDUSTRY IN EUROPE: EVIDENCE FOR GERMANY
}

\author{
Zamorina Anastasiia \\ National Research University, \\ Higher School of Economics Moscow, \\ Myasnitskaya 20, Moscow: Russia \\ anzamorina@gmail.com
}

\begin{abstract}
The aim of the study is to evaluate the influence of agglomeration effects on corporate performance in Germany. The assessment carried out by investigating the effects of localization and urbanization. For this reason, the work was presented to the theoretical basis; it formulated the problem, methodology of the research and analyzed the influence of various factors on the number of employees in leading industries of Germany. We use the Panel data, a large-scale German establishment survey covering around 3477 companies of 9 industries located in 83 cities (14 lands). The study covers the period $2007-2014$ years. The paper presents a linear model and two nonlinear models - the model with the addition of the square of companies' age and the model using the natural logarithm of the number of employees. The best model was chosen by using Akaike information criterion (AIC) and Schwarz (BIC), i.e. the linear model. The study found that localization effects have a positive impact on the number of employees, while the effects of urbanization - negative. In addition, it most strongly depends on the number of employees by region and industry. In the largest regions there is the largest population and respectively, the number of workers in it, so the agglomeration effects in the populous region is higher than in the other regions. The age of the company has a positive effect on the company's number of employees: with an increase in the age of 1 year, the number of employees is increased by 21 people.
\end{abstract}

Keywords: spatial concentration, agglomeration effects, localization externalities, urbanization externalities, productivity.

\section{Introduction}

The modern condition of the world economy is characterized by the increasing differentiation of regions. Regions being more competitive attract and concentrate factors of production that are originally limited. That is why today, when industry is actively developing, one of the most important conditions of development and competitiveness is the enhancement of social organization forms - concentration, cooperation and merger. The nature of production concentration emerges in the increase of enterprise sizes and in distribution of production volume in the industrial sectors across ventures of equal size. It is traditionally considered that the main measures of industrial production concentration are the size of an enterprise, which is defined by the annual production volume, annualized quantity of employees, annualized revenue and average venture size in the sector and so on. 
The problem of spatial concentration in industry is of relevance today, since it includes an economic effect in itself. Because of the increased size of companies and volume of production, the technical-and-economic indexes are improved. Also, due to the concentration of high production powers, labour and material resources at a single enterprise, there is a possibility for a more efficient and economical way of using the main production resources, such as raw materials, labour force and hardware. Therefore, it is possible to lower the costs of production and increase workforce productivity.

Economic activity often concentrates in places with plenty of natural resources. The differences in geographical distribution of resources and economic activity cause differences in wages, living standards and welfare as well asvarious level of control upon region development.

Most of companies in the country that work in one sphere are usually spatially concentrated. Subsequently, suppliers, additional services and commercial activity develop in close proximity to such production localization. Some business activities can be distributed across a large territory while goods are also dispatched on a great distance (McCann 2001).

The economic reason that underlies the unequal distribution of production is the advantages that are called external economies (Marshall 1890) or agglomeration effects. Joint agglomeration effect (localization effects + urbanization effects (Jacobs 1969) define the level of concentration of the production forces in a defined sphere of activity in a particular region. The changes in agglomeration effects should cause relevant changes in production powers disposal (Kutsenko 2012).

The object of this research is to evaluate the influence of agglomeration effects on corporate performance in main industrial sectors in Europe on the example of Germany.

To achieve the objective one should measure the influence of agglomeration effects on regional development and productivity of companies. That's why during this research the author estimates the influence of localization and urbanization effects on the level of Germany regions (NUTS 1: 14 states, in which 83 cities are located). Analysis covers the period from 2007 to 2014 and 21102 observations of 3477 German companies, activity of which falls into 9 different industrial branches.

The research is structured in the following way: The first part consists in review of theoretical and empirical literature concerning spatial concentration of industry, definition of main terms and assignment of contradictory statements on the analyzed sphere; In the second part the main empirical questions are described, hypotheses are developed; The third part specifies the research methods and database; The fourth part demonstrates the results of the research.

\section{Literature review}

Economic activity is established, grows and develops in the geographic space. Natural resources are distributed spatially in non-uniform manner; usually they are concentrated in some areas, while their number is insufficient or non-existent elsewhere. Economic activity is therefore concentrated in the areas rich in natural resources. The differences in geographical distribution of resources and economic activities generate differences in wages, living standards and well-being, as well as varying degrees of control over the local development of regions (Furtuna et al. 2014).

Competitive German industry provides constant leadership in many areas of industrial production. As the industry in many industrialized countries, German industry remains at the moment under the influence of a number of structural changes, which are expressed in the loss of its position in 
effect of high competition and displacement of sales markets, as well as in connection with the processes of mergers and acquisitions.

Despite this fact however, highly developed industry in Germany still remains the mainstay of the German economy and thanks to its wide base provides jobs for millions of workers in the industry as reported by the official website of Germany statistics ${ }^{1}$. The network of branches and manufacturing facilities of the German companies is located in many countries.

German industry brings together a number of leading industries allowing the state to occupy a leading position in the list of industrialized powers. The lists includes vehicle, metallurgy and chemical industry, electronics, machine tools, as well as light industry. According to the statistics, it accounts for about 40\% of GDP, with total sales for 2012 - 1,957,653 million EUR a year and involves 8 million employeeswhich represents $24.7 \%$ of the total number of people employed in Germany ${ }^{2}$.

Most companies in the country that are developing in the same industry tend to be spatially concentrated. Subsequently, suppliers, support services and commercial activities develop in the vicinity of such industry localization. Some activities can be spread out over a large area and the products are also shipped over long distances (McCann 2001).

The spatial behaviour of the company depends both on the individual attributes of the activities of production as well as geographical features of the region. In the regions with strong industrial sector any change in its economic performance will have a large cumulative effect on the whole region (Furtuna et al. 2014).

To cope with these two contradictory phenomena of globalization and general administrative management at the regional level, the identification of areas of economic concentration in one industry helps to solve the issues of cooperation between the companies. Such cooperation between the companies located in the same area is the synergy in daily operations (such as economies of scale in infrastructure cost allocation, and group rates for the costs), but also opens up the new opportunities and win-win situations, such that all of the individual companies and the region as a whole achieve benefits and financial gains. In this regard, (Pavlinek 2005), there are two distinctive attributes of new investments: embeddedness (integration in the local and regional economy) and dependence on the choice of the path (forgotten or not used before investment capital) (Furtuna et al. 2014)

Economic reasons underlying the uneven distribution of industry in the region is the advantage that Alfred Marshall called external economies (similar to the internal economy of scale) or the agglomeration effect. These economies are external because they appear outside of each individual company, in the process of complementarity. Maximization of internal economies management of the company must answer the questions "how much" and "how" to produce if it wants to maximize the savings of foreign - "Where?" and "with whom and how to communicate?" (Kutsenko 2012).

At the moment, agglomeration effects are traditionally divided by 2 types: the effects of clustering (localization) and the effects of urbanization. The effects of localization are also called the Marshallian effects or MAR-effects (the first letters of the names of scientists Marshall, Arrow, Romer). The effects of urbanization are often called Jacobs effect in recognition of the American researcher Jane Jacobs, who described their features as first (Jacobs 1969).

Both effects, being born in the process of co-localization of enterprises, have become factors in further concentration of the productive forces. However, if the effect of clustering occurs with

\footnotetext{
${ }^{1}$ https://www.destatis.de/DE/Publikationen/StatistischesJahrbuch/StatistischesJahrbuch2012.pdf?__blob=publicationFile

2 https://www.destatis.de/DE/ZahlenFakten/Indikatoren/LangeReihen/Arbeitsmarkt/Irerw013.html
} 
co-localization of enterprises in the general area of activity, the effect of urbanization appears at a concentration in a single area of all organizations, regardless of whether there is closeness between their object of activity whether not (Kutsenko 2012).

In fact, the effects of localization and urbanization refer to a number of external economies. Each of these economies has a different importance (weight) for different activities. Some of these externalities easily internalized by firms (e.g., saving on transport costs), other (primarily related to innovation) - require effort. Moreover, similarly as the other types of externalities, agglomeration externalities may be both positive and negative. In this case, they induce a centrifugal effect, forcing the company to leave the rational given the location and / or activity. Whatever it was, it is considered that the total agglomeration effect (+ localization effects of urbanization) determines the level of concentration of the productive forces in a particular activity in a given region. A change in the agglomeration effects should induce corresponding changes in the distribution of productive forces (Kutsenko 2012).

When considering the spatial concentration of industry in economic terms, we must: highlight the benefits, as well as find out what is the economic impact of this phenomenon.

The first step is to focus on the impact of two types of positive effects of agglomeration: localization and urbanization effects. Localization effects include the ones that arise from the effects of spatial concentration of enterprises from the same industry. The effects of urbanization arise from the spatial concentration of various industries. Diversity contributes to development of the ideas through cross-exchange of knowledge and allows their distribution in a variety of industries (Jacobs 1986; Strange 2004; Frenken 2007; Baldwin 2010).

Marshall investigated the effects of urbanization and localization in the works of 1890, highlighting three essential aspects:

- Combining workers to create a worthy competitive workforce, reducing the cost of labour recruitment and workers training and reducing the risks for both the employer and the employee (Strange 2004);

- Transfer of knowledge and skills improves performance. The necessity for communication of workers in the same industry to ensure transfer of skills and abilities (Jaffe 1993; Strange 2004; Baldwin 2010);

- Only one supplier frees economies of scale, from which all businesses located in a particular region and in a particular industry benefit.

Therefore, by increasing the scale of production and businesses' technical and economic indicators are improving also due to the concentration of large productive capacity, labour and material resources at the same enterprise, it is possible to use the basic elements of production, such as raw materials, labour and equipment more efficiently and effectively. Thus, it is possible to reduce production costs and improve productivity. This is the economic effect of the concentration.

However, apart from the effects of localization and urbanization there is also a «deglomeration» phenomenon - effects working in the opposite direction. For example, in the areas with high population density, overcrowding has the adverse effects: an increase in land prices, traffic problems, pollution and over-voltage infrastructure. All these effects have a negative impact on performance (Eckey 2010).

In order to assess the spatial concentration of industry, the researchers selected the number of employees as the dependent variable. Thus, using the statistics that characterize the industry in the region, Marcel Fafchamps (2007) attempted to prove the importance of the external effects of agglomeration through a regression analysis according to the industry employment growth on 
such variables as the "specific location", "competition" and "diversity". Evidence of agglomeration impact on economic growth is taken as evidence of the performance impact. The validity of this approach can be assessed in two ways: by direct monitoring of performance and by comparing the results obtained with allowance for the growth of employment with variables such as "power", "investment" and "entry / exit of firms." Results of the study showed that employment in the industry has a negative correlation with growth of production, employment, capital and a number of enterprises. During the research it was also revealed that growth has a negative impact on industry concentration: areas and industries in which enterprises have the same size, tend to grow faster in terms of production, employment and capital. Marcel Fafchamps states that in areas with a uniform distribution of employment in various industries the increase of production, employment, capital and the number of firms is much lower. However, it may be noticed that the study identified a number of contradictory arguments of the researchers, for example that agglomeration variables have almost the opposite effect on the overall industry growth in Morocco than the one they have on the individual companies involved in the industry. In addition, using the same data set, Fafchamps and El Hamine (2004) evaluated the effect of agglomeration variables on wages and total factor productivity at the level of individual enterprises and obtained the opposite result of research - competition lowers productivity, whereas diversity raises it. Thus, we can say that there is the influence of agglomeration on growth of a number of company performance indicators such as productivity growth, capacity, capital and employment.

In addition to employment, spatial concentration of the industry can be evaluated in terms of population of the regions. Thus, in the European Union has developed a standard by which regions are divided into NUTS 1, NUTS 2 and NUTS 3 levels (nomenclature des unites territorial's statistics - the division of regions into territorial units) to generate statistical data. Areas of the European cities with populations over 500,000 have a greater effect of agglomeration, indicating greater concentration of work in urban areas, which in turn has contributed to generation of strong agglomeration effects in recent years. These facts indicate the presence of agglomeration economy in the European countries in recent decades (Artis et al. 2010).

Strong impact on the performance of the location of the enterprise should be noted, both in industry and services, supporting the idea that the productivity of the enterprises can be enhanced by the effects of agglomeration in the areas with high population density. Enterprises located in areas with a high density of employees are more productive than businesses located in less densely populated areas. Moreover, the results of the evaluations of the GMM system allow us to interpret that the productivity of enterprises is higher in regional facilities with higher population density (Fuchs \& Ludewig 2010, 2013).

Continuing the idea that the differences caused by the level of education of labour force and social infrastructure in a particular region affect the level of spatial concentration of industry, it is necessary to pay special attention to other regional differences, for example to the size of the regional units. For example, in Germany the performance data are available on so-called Kreise. France, Italy and Spain have similar levels of inequality of regional labour productivity. However, the US States cover a larger area than the average Kreise, Provincie, Provincias or Europe. Therefore, it should be noted that the comparative evaluation of regional performance among the European countries and the United States must be performed with extreme caution, since the average size of the regional units is very different. (Ciccone 1999, 2001, 2002).

Thus, it can be concluded that when comparing a spatial concentration of the industry in different regions it is necessary to take the regional differences in performance into account. Characteristics 
of the region affect the performance of enterprises located in a particular area (Marshall 1890). It is necessary to pay attention to the works of Glaeser (1992) and Henderson (1995), which also focused attention on the impact of regional indicators on the level of development of industrial enterprises (Fuchs \& Ludewig 2010, 2013).

However, differences in the level of education or public infrastructure may not be the main cause of differences in regional performance. Therefore, special attention is paid to the role of agglomeration effects, which describe all the factors that affect the performance of enterprises. For example, a greater variety of services is more visible than in the cities than in small settlements. In addition, companies that are located in close proximity to other enterprises in the same industry tend to learn more and more quickly on the new technologies in the market. Such enterprises are generally more productive than those that are separated from an industry (Ciccone 1999, 2001, 2002).

Thus, for the development of productivity in the region, increase in enterprises and improvement of the competitiveness of the regions, there is need for research on the problem of the spatial concentration of industry. Therefore, a question of the possible ways of measuring the concentration arises. Thus, the presence of agglomeration effects indicates the presence of spatial concentration of industry. However the agglomeration effects of the economy can in turn be estimated using the GMM system (Generalized Method of Moments - generalized method of moments). The GMM system and the results obtained by this study are important for the study of agglomeration economy annual basis, that enables tracking how these findings have changed over time and can control how the factors that affect the spatial dependence change (Artis et al. 2010).

The theme of spatial concentration of industry has been developing from the time of Marshall in 1920. Modern works are mainly based on extracts from the research of Marshall (1920), Krugman (1991), Ciccone and Hall (1996), Ellison and Glaeser (1992, 1997), Duranton and Overman (2002) et al. Nowadays there are various indices for evaluating spatial concentration - index of Ellison and Glaeser (1997), Rysman and Greenstein (2005), Mori, Nishikimi, and Smith (2005), Duranton and Overman (2005) et al. A method of estimating the spatial concentration submitted by Duranton and Overman (2005) is significantly different, not only in evaluation method, but in the results, from the index of Ellison and Glaeser (1997). According to Scott Duke Kominers (2008), usage of agglomeration indexes is very "cumbersome", , so the best solution would be a combination of agglomeration index measurement in the style of Guillain and Le Gallo (2007). However, it is not clear how to simulate such an index. Thus, it can be concluded that the index for evaluating the spatial concentration, which would at the same time be not "bulky" in the application and could be modelled has not been found yet. These facts point out at the importance and relevance of the topic of spatial concentration and the need to study the issue.

To assess the effects of agglomeration, the researchers construct the regression models using the following statistics: the level of employment in industry and services, data on the level of education provided in the documents of the Census (Ciccone 1999, 2001, 2002), and the "power" , "investment" and «input / output firms» (Fafchamps 2007). For more in-depth analysis and evaluation of factors of labour relations between the regional size and effectiveness of the company they used data on the level of hotel companies, taking the business policy of the company, enterprise development, innovative technologies, the wage rate workers, working hours (hours worked) and other general information into account (Fuchs \& Ludewig 2010, 2013).

To assess the effects of agglomeration, two simple models can be used: one based on spatial externalities (or external effects) and the other based on non-market costs, bringing the increasing 
revenues. Both models show similar results, depending on the performance and density of employment in certain geographical levels (regions, provinces, counties, lands, etc.).

Investigation of the spatial concentration of industry devoted to articles with empirical analysis of data in Russia, the European Union and the United States of America. To this end, the researchers carried out a comparative analysis between different regions to assess the effects of agglomeration, comparing them between countries and with the aim to identify the factors for increasing the competitiveness of a region. For example, empirical results of the assessment in the US and the EU have shown that in the selected European countries (France, Germany, Italy, Spain and the UK), the agglomeration effect is only slightly lower than in the US, the estimated elasticity of average labour productivity in relation to the density of employment is $45 \%$ compared to $5 \%$ in the USA. Labour productivity in the five most productive Kreise is almost two and a half times greater than productivity in the five least productive Kreise. France, Italy and Spain have similar levels of inequality of regional labour productivity. The country with the lowest regional differences in average productivity is United Kingdom. Thus it is possible to draw the following conclusions: - Firstly, the agglomeration effects among these European countries differ slightly and are almost at the same level in each country. Secondly, the power of agglomeration effects is similar between the US and the European countries (Ciccone 1999, 2001, 2002).

Thus, it can be argued that much of the regional differences in performance is due to agglomeration effects, which have greater impact on the regional differences in performance than for example in education (Ciccone 1999, 2001, 2002).

In addition to the influence of the spatial concentration of industry on the activities of the existing companies, it is worth to note the impact of the presence of spatial concentration of establishing the new enterprises in the industry in the region. For example, in the areas with a high concentration of the effect of spatial concentration of industry, the influence on the emergence of new companies processes in the following way: the market emergence of companies operating in the region with a high concentration of industry leads in most cases to withdrawal by the company from autonomous existence and its acquisition by a major company in the industry. The presence of spatial concentration helps to "survive" a new company on the market, successfully enter the market and even to take a leading position in it. This fact is typical for the industry however has quite the opposite effect on the service sector (Weterings \& Marsili 2012).

It should be noted that the theme of spatial concentration of the industry is actively studied by the scientists worldwide. The author of this study has analyzed many empirical studies in the field of economics of agglomeration. Then he summarized the conclusions of the researchers obtained in different regions, for example such as a province of China (Gao 2004), the EU (Lindqvist 2009), regions of the UK (Anastassova 2006) as well as the results obtained at the level of individual enterprises and companies, e.g. tens of thousands of companies in Russia (Vorobyev et al. 2010) and in a number of industrial enterprises in the United States (Henderson 2003). It is necessary to pay attention to the large number of research on the effects of agglomeration, however, all of the studies are separated from each other and cannot pretend to confirm or refute the hypothesis on the influence of external economies in general. Therefore, agglomeration variables have almost the opposite effect on the overall industry growth in Morocco than the one they have on the individual companies involved in the industry. Also, the assessment of impact of agglomeration variables on wages and total factor productivity at the level of individual enterprises in a number of regions leads to the opposite results of research - competition drives productivity, diversity raises it (Marcel Fafchamps \& El Hamine 2004). 
The effect on the performance of external economies is divided into elasticity of performance by size of the city (Jacobs effects) and the sector size of the region (MAR-effects) and often lies between $3 \%$ and $8 \%$. Based on this, a conclusion about the absence of the need for governmental intervention in the territorial distribution and strengthening the agglomeration effects arises. In all known empirical studies the effects of agglomeration are measured on the scale of concentration of the productive forces. That means that if there is a relatively large concentration of industry or employment in a particular sphere of activity in the region (relative to the other regions under study), it is concluded that the effects of agglomeration in the region / activity are relatively large (Kutsenko 2012).

\section{Research problem and hypotheses}

International theoretical and empirical literature on spatial concentration of industry (Mills 1967; Mirrlees 1972; Krugman 1993; Quigle 1998; Shefer 1973) demonstrates that occupancy of companies in close proximity to each other within the large agglomerations increases productivity and growth rate due to the effects related to the scale factors and market demand, saving transaction costs and sharing some of the more productive use of factors of production. The special role of these effects is gained with development of the economics of knowledge. Moreover, agglomeration economy has a different effect on enterprises of different size groups and more beneficial to manufacturers of products with a low level of standardization than the mass producers. Negative externalities of territorial concentration and development of information technology lower its benefits and create incentives for the dispersion (Gonchar 2006).

Thus, it can be stated that industrial production has a significant impact on the socioeconomic condition of the economy and therefore the formation of industrial policy at the federal, regional and municipal levels is an essential component of the present stage of development in Europe. Using this tool, the state controls the entire market environment, as well as individual sectors and enterprises to enhance their commercial and budgetary efficiency. Therefore, the state industrial policy aims at creating conditions to stabilize and improve production efficiency and competitiveness as well as increase the industrial production (Zaitsev 2008).

The object of this research is to evaluate the influence of agglomeration effects on corporate performance in the main industrial sectors in Europe on the example of Germany. To achieve this aim the following objectives are stated:

1. Calculation of agglomeration effects (localization and urbanization) on the example of German industry for the period 2007 - 2014;

2. Construction of a regression model to estimate the impact of various factors, including the agglomeration effects on the number of employees in the enterprise;

3. Drawing the conclusion on the impact of agglomeration effects in Germany for the years $2007-2014$ based on the findings of presence of the spatial concentration of industry.

Formulation of a number of hypotheses to be proved or disproved in the progress of research is possible:

1. If the company, located in a given region of the country, depends on a certain kind of natural resources, it will feature a high level of spatial concentration and vice versa;

2. Companies with headquarters will have a greater measure of spatial concentration in the cities than in small villages, as the head office is usually located in big cities. 


\section{Description of the methods and information base of research}

The information base of the research consists in foreign and domestic theoretical and empirical researches, publicly available statistics, namely documents published on the «Eurostat» site as well as on the "Federal Statistical Office" website in Germany (Statistisches Bundesamt), as well as database independently created by the author that includes the number of employees, age of the company, market share, company's investment in the short and long term perspective, company's revenue, effect of localization and urbanization in Germany formed on the basis of the data downloaded from the Thomson Reuters database and calculations conducted by the author with the help of indice-based estimation of agglomeration effects. In addition, the qualitative analysis was performed on the basis of scientific knowledge obtained in the framework of the "European city and regional development planning» faculty in the University of Humboldt in Berlin in 2013.

Panel data of 21102 observations studied in this paper for 3477 German companies located in 83 cities (14 Länder - Table 1) 9 industries (Tab. 2). The study period - 2007-2014.

Table 1. Regions of Germany

\begin{tabular}{|c|l|}
\hline ID, region № & \multicolumn{1}{|c|}{ Name of the State (NUTS 1) } \\
\hline 0 & No data \\
\hline 1 & Bavaria \\
\hline 2 & Baden-Württemberg \\
\hline 3 & North Rhine-Westphalia \\
\hline 4 & Hesse \\
\hline 5 & Saxony \\
\hline 6 & Lower Saxony \\
\hline 7 & Rhineland-Palatinate \\
\hline 8 & Thuringia \\
\hline 9 & Brandenburg \\
\hline 10 & Saxony-Anhalt \\
\hline 11 & Mecklenburg-Western Pomerania \\
\hline 12 & Schleswig-Holstein \\
\hline 13 & Saarland \\
\hline 14 & Bremen \\
\hline 15 & Berlin \\
\hline 16 & Hamburg \\
\hline
\end{tabular}


Table 2. Sectors in Germany

\begin{tabular}{|c|c|c|}
\hline ID, sector № & Name (original) & Description \\
\hline 10 & Energy & Energy and all related industrial services \\
\hline 15 & Materials & Mineral resources, chemical products \\
\hline 20 & Industrials & Industrial Goods, transport, machine building, automotive \\
\hline 25 & $\begin{array}{l}\text { Consumer } \\
\text { Discretionary }\end{array}$ & Industrial Goods and Services, automobiles and spare parts for vehicles \\
\hline 30 & Consumer Staples & Products of the chemical industry and other mineral resources \\
\hline 35 & Health Care & Chemicals, pharmaceuticals and medicine \\
\hline 40 & Financials & The financial center, banking, investment companies \\
\hline 45 & $\begin{array}{l}\text { Information } \\
\text { Technology }\end{array}$ & Energy, Industry \\
\hline 55 & Utilities & Other industry sub-sectors \\
\hline
\end{tabular}

STATA software was used to estimate the regression model.

Applied scientific methods of data collection and comparative analysis and graphical analysis method were used in this research (descriptive statistics are presented in tables $3-4$ ).

Table 3. Descriptive Statistics: how the average values of the variables change in the period under review

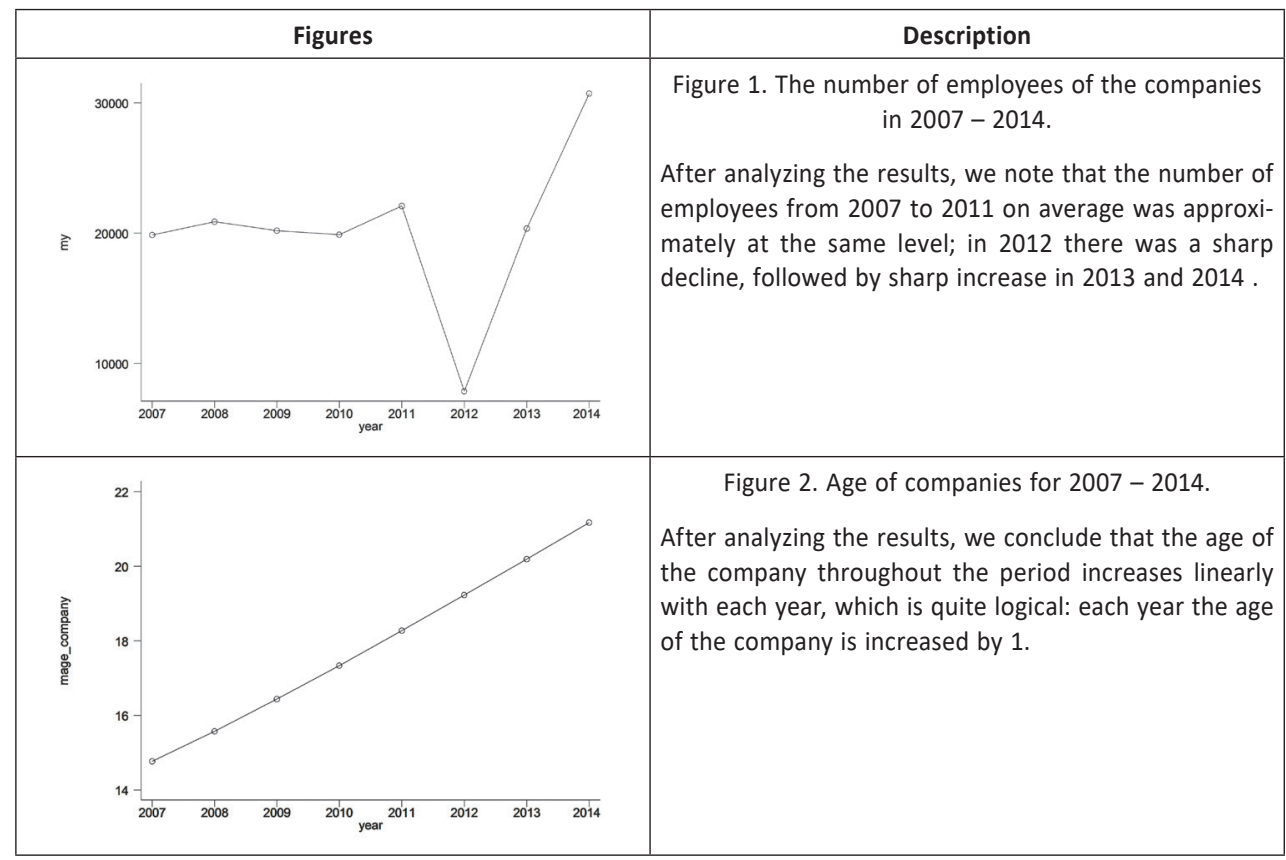




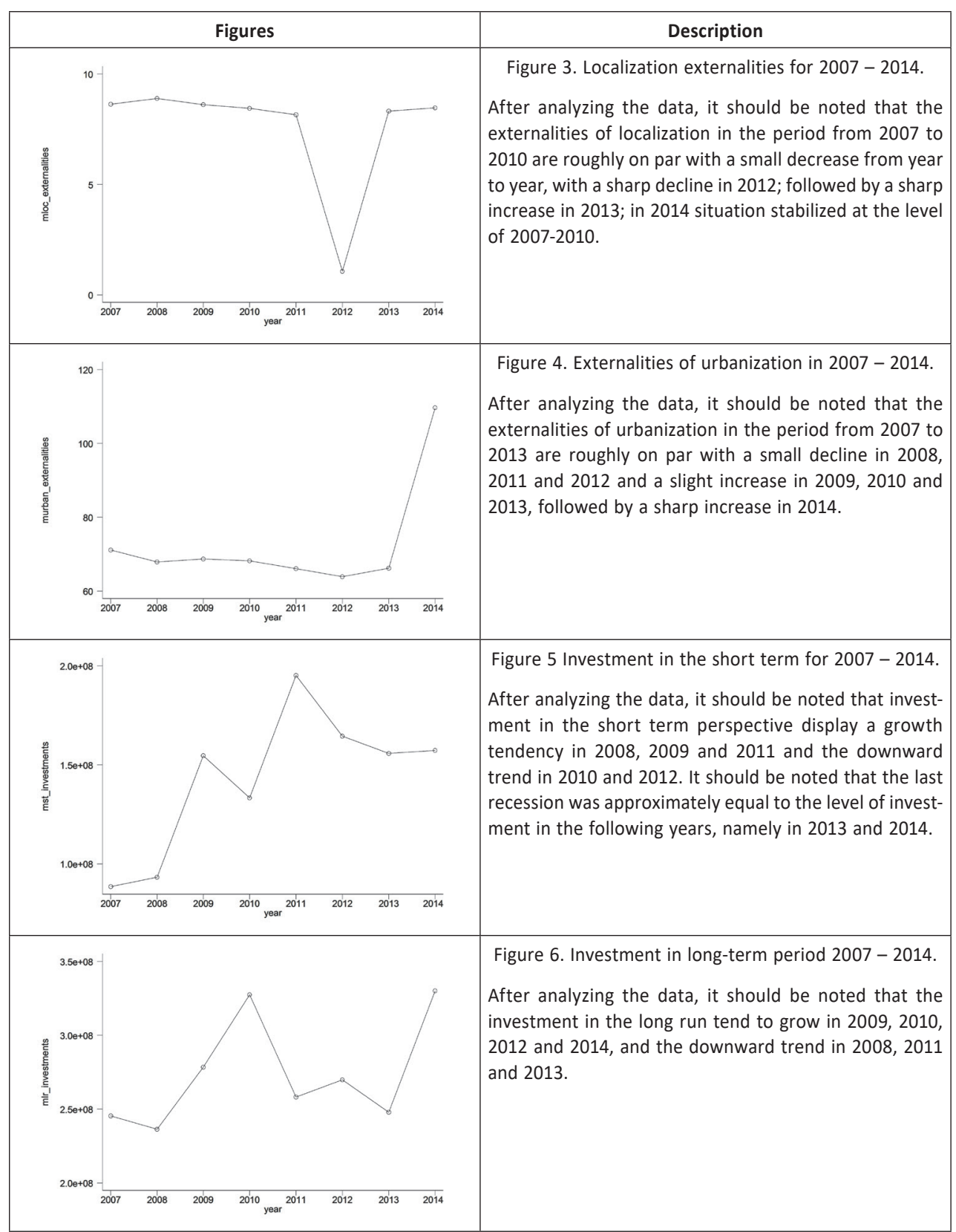




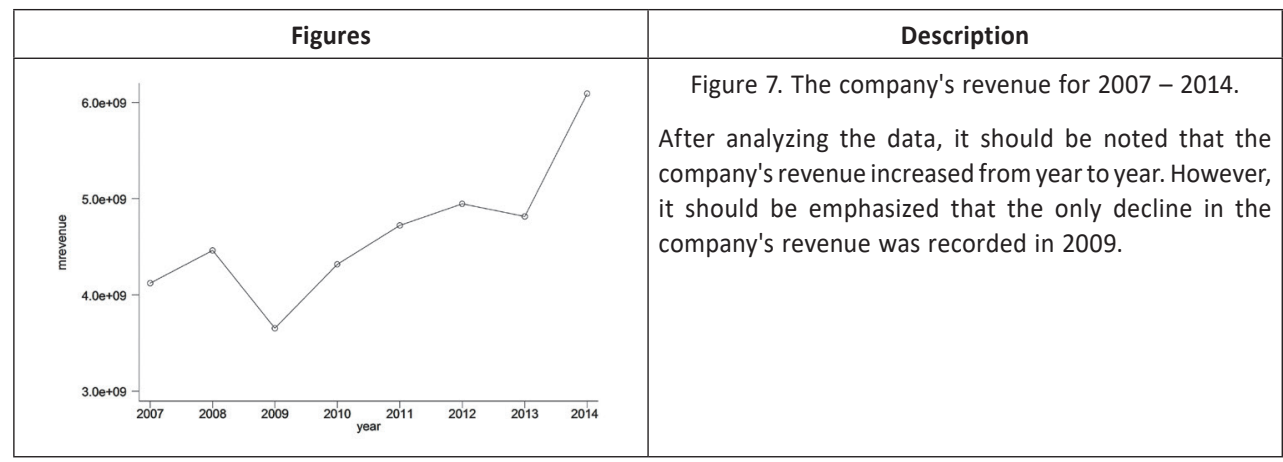

Table 4. Descriptive Statistics

\begin{tabular}{|c|c|c|c|c|}
\hline Variable & Mean & Standard deviation & Minimum value & Maximum value \\
\hline Year & \multicolumn{4}{|c|}{2007} \\
\hline Employees & 19851,35 & 69401,73 & 1 & 512347 \\
\hline Age of company & 14,76569 & 28,59324 & 0 & 122 \\
\hline Localization externalities & 8,628555 & 5,928393 & 0,0033825 & 13,14207 \\
\hline Urbanization externalities & 71,11219 & 78,74146 & 39,28878 & 476,6418 \\
\hline Investment in short term & 88400000 & 262000000 & 0 & 1530000000 \\
\hline Investment in long term & 245000000 & 651000000 & 0 & 3420000000 \\
\hline Revenue & 4120000000 & 10500000000 & 58140 & 58000000000 \\
\hline Market share & 0,0002879 & 0,0007898 & 0 & 0,0046023 \\
\hline Region & 4,251295 & 4,19183 & 0 & 16 \\
\hline \multirow[t]{2}{*}{ Sector } & 21,85377 & 8,636728 & 10 & 55 \\
\hline & \multicolumn{4}{|c|}{2008} \\
\hline Employees & 20883,81 & 70891,51 & 2 & 512536 \\
\hline Age of company & 15,57599 & 28,69374 & 0 & 123 \\
\hline Localization externalities & 8,894689 & 6,132226 & 0,0037906 & 13,56503 \\
\hline Urbanization externalities & 67,88994 & 73,05725 & 37,00291 & 381,3641 \\
\hline Investment in short term & 93300000 & 304000000 & 0 & 1830000000 \\
\hline Investment in long term & 236000000 & 644000000 & 0 & 3490000000 \\
\hline Revenue & 4460000000 & 11000000000 & 33050 & 62300000000 \\
\hline Market share & 0,0002879 & 0,0007667 & 0 & 0,0045634 \\
\hline Region & 4,251295 & 4,19183 & 0 & 16 \\
\hline \multirow[t]{2}{*}{ Sector } & 21,85377 & 8,636728 & 10 & 55 \\
\hline & \multicolumn{4}{|c|}{2009} \\
\hline Employees & 20189,35 & 66538,1 & 7 & 477280 \\
\hline Age of company & 16,43955 & 28,76978 & 0 & 124 \\
\hline
\end{tabular}




\begin{tabular}{|c|c|c|c|c|}
\hline Variable & Mean & Standard deviation & Minimum value & Maximum value \\
\hline Localization externalities & 8,614269 & 5,938683 & 0,0050182 & 13,13731 \\
\hline Urbanization externalities & 68,69692 & 75,35248 & 36,89903 & 420,6856 \\
\hline Investment in short term & 155000000 & 531000000 & 0 & 3300000000 \\
\hline Investment in long term & 278000000 & 746000000 & 0 & 3320000000 \\
\hline Revenue & 3650000000 & 9140000000 & 8900 & 50700000000 \\
\hline Market share & 0,0002879 & 0,0007696 & 0 & 0,0044787 \\
\hline Region & 4,251295 & 4,19183 & 0 & 16 \\
\hline \multirow[t]{2}{*}{ Sector } & 21,85377 & 8,636728 & 10 & 55 \\
\hline & \multicolumn{4}{|c|}{2010} \\
\hline Employees & 19894,91 & 64574,21 & 21 & 467088 \\
\hline Age of company & 17,33621 & 28,8304 & 0 & 125 \\
\hline Localization externalities & 8,447413 & 5,811527 & 0,0043872 & 12,87305 \\
\hline Urbanization externalities & 68,18257 & 72,48373 & 36,31459 & 400,0586 \\
\hline Investment in short term & 133000000 & 585000000 & 0 & 4280000000 \\
\hline Investment in long term & 327000000 & 910000000 & 0 & 5080000000 \\
\hline Revenue & 4320000000 & 10900000000 & 42360 & 63900000000 \\
\hline Market share & 0,0002879 & 0,0007788 & 0 & 0,0048155 \\
\hline Region & 4,251295 & 4,19183 & 0 & 16 \\
\hline \multirow[t]{2}{*}{ Sector } & 21,85377 & 8,636728 & 10 & 55 \\
\hline & \multicolumn{4}{|c|}{2011} \\
\hline Employees & 22084,12 & 72641,99 & 23 & 471654 \\
\hline Age of company & 18,27634 & 28,86736 & 0 & 126 \\
\hline Localization externalities & 8,150802 & 5,713759 & 0,004625 & 12,5076 \\
\hline Urbanization externalities & 66,04661 & 71,51825 & 33,69342 & 402,5075 \\
\hline Investment in short term & 195000000 & 595000000 & 0 & 3110000000 \\
\hline Investment in long term & 258000000 & 691000000 & 0 & 4060000000 \\
\hline Revenue & 4720000000 & 11900000000 & 2760710 & 73500000000 \\
\hline Market share & 0,0002879 & 0,0007733 & 0 & 0,0049961 \\
\hline Region & 4,251295 & 4,19183 & 0 & 16 \\
\hline \multirow[t]{2}{*}{ Sector } & 21,85377 & 8,636728 & 10 & 55 \\
\hline & \multicolumn{4}{|c|}{2012} \\
\hline Employees & 7882,347 & 15419,36 & 29 & 66826 \\
\hline Age of company & 19,22654 & 28,8997 & 0 & 127 \\
\hline Localization externalities & 1,062702 & 0,4755587 & 0 & 1,36694 \\
\hline Urbanization externalities & 63,90337 & 67,49234 & 0 & 373,3614 \\
\hline Investment in short term & 165000000 & 529000000 & 0 & 3530000000 \\
\hline
\end{tabular}




\begin{tabular}{|c|c|c|c|c|}
\hline Variable & Mean & Standard deviation & Minimum value & Maximum value \\
\hline Investment in long term & 270000000 & 699000000 & 0 & 4070000000 \\
\hline Revenue & 4950000000 & 12200000000 & 2327450 & 72100000000 \\
\hline Market share & 0,0002879 & 0,0007662 & 0 & 0,0047886 \\
\hline Region & 4,251295 & 4,19183 & 0 & 16 \\
\hline \multirow[t]{2}{*}{ Sector } & 21,85377 & 8,636728 & 10 & 55 \\
\hline & \multicolumn{4}{|c|}{2013} \\
\hline Employees & 20361,35 & 68133,2 & 32 & 479690 \\
\hline Age of company & 20,19142 & 28,92365 & 0 & 128 \\
\hline Localization externalities & 8,322471 & 5,798661 & 0 & 12,74244 \\
\hline Urbanization externalities & 66,22462 & 75,23591 & 0 & 425,5727 \\
\hline Investment in short term & 156000000 & 506000000 & 0 & 3290000000 \\
\hline Investment in long term & 248000000 & 706000000 & 0 & 4820000000 \\
\hline Revenue & 4820000000 & 12200000000 & 2640390 & 74000000000 \\
\hline Market share & 0,0002879 & 0,0007798 & 0 & 0,0049876 \\
\hline Region & 4,251295 & 4,19183 & 0 & 16 \\
\hline \multirow[t]{2}{*}{ Sector } & 21,85377 & 8,636728 & 10 & 55 \\
\hline & \multicolumn{4}{|c|}{2014} \\
\hline Employees & 30708,22 & 80822,63 & 38 & 488824 \\
\hline Age of company & 21,17473 & 28,93559 & 0 & 129 \\
\hline Localization externalities & 8,469422 & 5,801196 & 0 & 12,88498 \\
\hline Urbanization externalities & 109,6897 & 351,6761 & 0 & 3333,332 \\
\hline Investment in short term & 157000000 & 346000000 & 0 & 1910000000 \\
\hline Investment in long term & 330000000 & 736000000 & 0 & 3790000000 \\
\hline Revenue & 6090000000 & 13600000000 & 17100000 & 74300000000 \\
\hline Market share & 0,0002879 & 0,0007902 & 0 & 0,005013 \\
\hline Region & 4,251295 & 4,19183 & 0 & 16 \\
\hline Sector & 21,85377 & 8,636728 & 10 & 55 \\
\hline
\end{tabular}

There is a strong direct linear relationship (Tab. 5) between the variables revenue and market share, market_share and Ir_investments, revenue and Ir_investments. Also, there is an average direct linear relationship between the variables and st_investments revenue, st_investments and market_share, st_investments and Ir_investments, urban_ext and loc_exter, urban_ext and industry. To avoid the problem of multicollinearity variables market_share, Ir_investments, st_investments and urban_externalities were excluded. 
Table 5. The correlation matrix

\begin{tabular}{|c|c|c|c|c|c|c|c|c|c|c|}
\hline & $>$ & 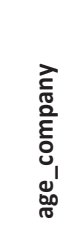 & 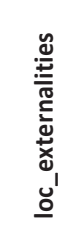 & 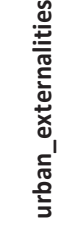 & 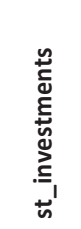 & 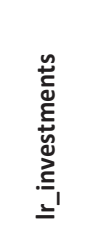 & 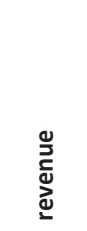 & 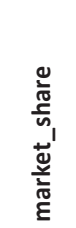 & 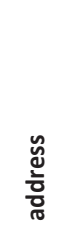 & 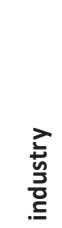 \\
\hline y & 1.00 & & & & & & & & & \\
\hline age_company & -0.01 & 1.00 & & & & & & & & \\
\hline loc_externalities & 0.16 & 0.26 & 1.00 & & & & & & & \\
\hline urban_externalities & -0.10 & -0.10 & -0.53 & 1.00 & & & & & & \\
\hline st_investments & 0.39 & 0.16 & 0.16 & -0.11 & 1.00 & & & & & \\
\hline Ir_investments & 0.54 & -0.06 & 0.05 & -0.12 & 0.38 & 1.00 & & & & \\
\hline revenue & 0.81 & -0.05 & 0.06 & -0.12 & 0.42 & 0.78 & 1.00 & & & \\
\hline market_share & 0.81 & -0.05 & 0.06 & -0.12 & 0.42 & 0.80 & 0.99 & 1.00 & & \\
\hline address & -0.09 & 0.11 & -0.11 & 0.19 & -0.09 & -0.06 & -0.05 & -0.05 & 1.00 & \\
\hline industry & -0.11 & -0.01 & -0.31 & 0.35 & -0.09 & -0.19 & -0.20 & -0.20 & 0.04 & 1.00 \\
\hline
\end{tabular}

Exclude: market_share, urban_exter, Ir_investment, st_investment

A method of identifying the regional economic clusters was also used, which is based on establishing the agglomeration effects. It is an agglomeration index of localization and urbanization. In order to calculate this value for the test regions of Germany one should provide data on geographical areas. Subsequently, calculating the index requires using of the statistical data on these geographical regions (Eckey et al. 2009).

The relevant indices used in this study are calculated on the basis of all employees of the companies, covered by social security allowances provided by the Federal Labour Office. The degree of specialization in the region, which may lead to localization externalities is measured using the Krugman specialization index (Suedekum 2006):

$$
\mathrm{KSI}_{\mathrm{z}}=\sum_{\mathrm{s}}\left(\left|\frac{\mathrm{L}_{\mathrm{zS}}}{\mathrm{L}_{\mathrm{z}}}-\frac{\mathrm{L}_{\mathrm{s}}}{\mathrm{L}}\right|\right),
$$

where, $s$ - sector $(s=1, \ldots, m) ; z$ - geographical area $(z=1, \ldots, n) ; L_{z s}$ - employment in the region $z$, and the sector $s ; L_{z}$-employment in the region $z ; L_{s}-$ employment in the sector $s ; L-$ employment in the country.

The diversity of activities in the region, which may lead to externalities of urbanization, is measured using the Herfindahl-Hirschman index (Combes 2000, Combes et al., 2004, Mameli et al., 2008):

$$
\operatorname{DIV}_{z}=\left[\sum_{s=1}^{\prime}\left(\frac{L_{z s}}{L_{z}}\right)^{2}\right],
$$

where, $s$ - sector $(s=1, \ldots, m) ; z$ - geographical area $(z=1, \ldots, n) ; L_{z s}$ - employment in the region $z$, and the sector $s ; L_{z}-$ employment in the region $z$. 
Importantly, the Herfindahl-Hirschman index used in this case has a different meaning than the conventional version of the Herfindahl-Hirschman index: in this embodiment the proportion of employment in businesses to economic activity in the region is used.

\section{Description of research results}

The dependent variable $(\mathrm{y})$ is the number of employees. This variable has been selected on the basis of theoretical and empirical researches, which are presented in the Table 6 .

Table 6. Investigation of the agglomeration effects in different regions

\begin{tabular}{|c|c|c|c|c|c|}
\hline № & Source & Object Analysis & $\begin{array}{l}\text { Dependent } \\
\text { Variable }\end{array}$ & $\begin{array}{c}\text { Confirmation of } \\
\text { influence on the } \\
\text { dependent variable } \\
\text { - localization } \\
\text { effect }\end{array}$ & $\begin{array}{l}\text { Confirmation } \\
\text { of influence on } \\
\text { the dependent } \\
\text { variable - effect of } \\
\text { urbanization }\end{array}$ \\
\hline 1 & $\begin{array}{l}\text { Henderson, } \\
\text { Kuncoro, Turner } \\
\text { (1995). }\end{array}$ & $\begin{array}{l}\text { Eight industries in } \\
\text { the United States } \\
\text { (in } 1970 \text { and 1987) }\end{array}$ & $\begin{array}{l}\text { Growth rate of } \\
\text { employment in the } \\
\text { industry }\end{array}$ & $\begin{array}{l}+ \text { (and for tradi- } \\
\text { tional and high-tech } \\
\text { industries) }\end{array}$ & $\begin{array}{l}+ \text { (only in the } \\
\text { case of high-tech } \\
\text { industries) }\end{array}$ \\
\hline 2 & $\begin{array}{l}\text { Baptista, Swann } \\
\text { (1999). }\end{array}$ & $\begin{array}{l}\text { Companies in } \\
\text { information } \\
\text { technology in } 39 \\
\text { US states and } 14 \\
\text { regions of the UK in } \\
1988 \text { and } 1991\end{array}$ & $\begin{array}{l}\text { Growth of } \\
\text { the company } \\
\text { (represented } \\
\text { by employment } \\
\text { growth) }\end{array}$ & + & - \\
\hline 3 & $\begin{array}{l}\text { Glaeser, Kallal, } \\
\text { Scheinkman, } \\
\text { Shleifer (1992). }\end{array}$ & $\begin{array}{l}170 \text { US cities } \\
\text { between } 1956 \text { and } \\
1987\end{array}$ & $\begin{array}{l}\text { Employment } \\
\text { growth }\end{array}$ & - & + \\
\hline 4 & Combes (2000). & $\begin{array}{l}341 \text { region in } \\
\text { France (from } 1984 \\
\text { to } 1993 \text { ) }\end{array}$ & $\begin{array}{l}\text { Employment } \\
\text { growth }\end{array}$ & - & $\begin{array}{l}+ \text { (for services) - } \\
\text { (for the industry) }\end{array}$ \\
\hline 5 & Almeida (2005). & $\begin{array}{l}\text { Manufacturing } \\
\text { companies in } 275 \\
\text { regions of Portugal } \\
\text { from } 1985 \text { to } 1994\end{array}$ & Salary growth & + & - \\
\hline 6 & Anastassova (2006). & $\begin{array}{l}\text { Areas of the UK } \\
\text { (Local Authority } \\
\text { District) in } 1998 \\
\text { and } 2003\end{array}$ & Hourly earnings & $\begin{array}{l}\text { (MAR effects are } \\
\text { not considered) }\end{array}$ & + \\
\hline 7 & Gao (2004). & $\begin{array}{l}\text { Mining and manu- } \\
\text { facturing industries } \\
\text { in } 28 \text { provinces in } \\
\text { China from } 1985 \\
\text { to } 1993\end{array}$ & Output growth & - & - \\
\hline
\end{tabular}




\begin{tabular}{|c|c|c|c|c|c|}
\hline 8 & $\begin{array}{l}\text { Vorobyev, Kislyak, } \\
\text { Davidson (2010). }\end{array}$ & $\begin{array}{l}10,663 \text { companies } \\
\text { from all regions } \\
\text { of the Russian } \\
\text { Federation } \\
\text { various activities } \\
(2001-2005)\end{array}$ & Profit growth & $\begin{array}{l}\text { + influence of } \\
\text { localization effects } \\
\text { is non-linear } \\
\text { (communication } \\
\text { in the form of an } \\
\text { inverted U) }\end{array}$ & + \\
\hline 9 & $\begin{array}{l}\text { Martin, Mayer, } \\
\text { Mayneris (2008). }\end{array}$ & $\begin{array}{l}\text { Companies in } \\
\text { France from } \\
1996 \text { to } 2004 \\
\text { (a total of } 94573 \\
\text { observations) }\end{array}$ & $\begin{array}{l}\text { Added value (by } \\
\text { companies) }\end{array}$ & + & - \\
\hline \multirow[t]{2}{*}{10} & \multirow[t]{2}{*}{$\begin{array}{l}\text { Fafchamps, Hamine } \\
\text { (2007) }\end{array}$} & \multirow{2}{*}{$\begin{array}{l}\text { Industrial } \\
\text { enterprises in } \\
\text { Morocco from } 1985 \\
\text { to } 2001\end{array}$} & $\begin{array}{l}\text { Number of } \\
\text { employees of the } \\
\text { Company }\end{array}$ & + & - \\
\hline & & & Wage growth & + & + \\
\hline 11 & $\begin{array}{l}\text { Artis, Curran, } \\
\text { Sensier (2010) }\end{array}$ & $\begin{array}{l}\text { Industrial produc- } \\
\text { tion and services in } \\
\text { France, Germany, } \\
\text { Ireland, Italy, Spain } \\
\text { and the UK from } \\
1980 \text { to } 2006 \text {. At } \\
\text { the regional level } \\
\text { NUTS } 2 \text { and NUTS } \\
\text { 3. }\end{array}$ & $\begin{array}{l}\text { Number of } \\
\text { employees of the } \\
\text { Company }\end{array}$ & $\begin{array}{l}\text { + for the entire } \\
\text { sample from } 1980 \\
\text { to } 2006 \text { in industry } \\
\text { - for the period } \\
1980 \text { - } 1990 \text { in } \\
\text { industry } \\
\text { + for NUTS } 3 \\
\text { regions in the } \\
\text { service sector }\end{array}$ & $\begin{array}{l}\text { - for the entire } \\
\text { sample from } 1980 \\
\text { to } 2006 \\
+ \text { in the period } \\
1980 \text { - } 1990 \text { in } \\
\text { industry } \\
\text { + for NUTS } 3 \\
\text { regions in the } \\
\text { service sector }\end{array}$ \\
\hline 12 & $\begin{array}{l}\text { Ciccone (1999, } \\
2001,2002)\end{array}$ & $\begin{array}{l}628 \text { regions (NUTS } \\
\text { 3) in France, } \\
\text { Germany, Italy, } \\
\text { Spain and the UK }\end{array}$ & $\begin{array}{l}\text { Number of } \\
\text { employees, level of } \\
\text { education }\end{array}$ & + & + \\
\hline 13 & $\begin{array}{l}\text { Fuchs, Ludewig } \\
(2010,2013)\end{array}$ & $\begin{array}{l}439 \text { Kreise } \\
\text { Kreisefreie Staedte } \\
\text { (NUTS 3) - } 20106 \\
\text { observations for } \\
4891 \text { companies }\end{array}$ & $\begin{array}{l}\text { Employment, } \\
\text { number of } \\
\text { employees, number } \\
\text { of hours worked } \\
\text { by employees of } \\
\text { companies }\end{array}$ & $\begin{array}{l}+ \text { (especially for } \\
\text { regions with high } \\
\text { population density) }\end{array}$ & - \\
\hline 14 & $\begin{array}{l}\text { Weterings, Marsili } \\
\text { (2012) }\end{array}$ & $\begin{array}{l}\text { Manufacturing } \\
\text { companies in } 40 \\
\text { regions (NUTS 3) of } \\
\text { Holland 1994-1998 } \\
\text { (2005) }\end{array}$ & $\begin{array}{l}\text { Number of } \\
\text { employees of the } \\
\text { Company }\end{array}$ & + & - \\
\hline 15 & $\begin{array}{l}\text { Rosenfeld, Franz, } \\
\text { Heimpold (2005) }\end{array}$ & $\begin{array}{l}\text { Production } \\
\text { company in } \\
\text { Germany in the } \\
\text { period 1995-2000 }\end{array}$ & $\begin{array}{l}\text { Number of } \\
\text { employees }\end{array}$ & + & + \\
\hline 16 & $\begin{array}{l}\text { Damijan, Konings } \\
\text { (2013) }\end{array}$ & $\begin{array}{l}\text { Manufacturing } \\
\text { companies in the } \\
\text { regions of Slovenia } \\
\text { (NUTS 3) in the } \\
\text { period 2000-2008. } \\
\text { (reviewed from } \\
30753 \text { to } 42168 \\
\text { each year) }\end{array}$ & $\begin{array}{l}\text { Employment, } \\
\text { number of } \\
\text { employees }\end{array}$ & + & + \\
\hline
\end{tabular}

Source: №1-9 (Kutsenko ES 2012), №10-16 - compiled by the author. 
Since most research studied the number of selected employees of the company as the dependent variable to evaluate the effect of agglomeration effects, the author has decided to measure the impact of externalities on this variable. There are also publicly available data on this variable. For "level of education" and "number of hours worked" variables such data can be obtained by surveying all employees.

As control variables, "localization externalities" and "externalities of urbanization" and "age of the company" were chosen, respectively.

The independent variables include the "revenue", "region" which houses the company, "industry" in which the company operates, "investment in the short term", "investment in the long run" and "market share".

\section{Linear model}

At first, we constructed a linear regression model (pooled regression), results of which are presented in Table 10 (1). It represents a pass-through regression for all years and all the companies, without consideration to the panel structure of data and estimated using the ordinary least squares method.

The adjusted coefficient of determination (Adj R-squared) is equal to 69\%, which means that $69 \%$ of the variation of the number of employees is explained by the model. All coefficients are significant at the $1 \%$ level of significance, except the age of the company ( $5 \%$ level significance).

The next stage is structuring a model ((2), Tab. 10), taking the panel structure of the data into account.

Regression «within» (model with deterministic (fixed) effects) - is the initial regression model rewritten in terms of deviations from the mean values of the variables over time. It is convenient because it allows for eliminatation unobserved individual effects from the model. Evaluation of the model is produced by ordinary OLS. This is the method for estimating the coefficients $\beta$ of the regression model with deterministic individual effects (FE).

Instead of a loc_extern variable the urban_extern variable should be applied to look at the impact of the effect of urbanization, since these variables together cannot be included due to their correlatation ((3), Tab. 10).

From these results it is clear that the relationship between the variables remained unchanged. It turned out that loc_extern affect positively and urban_extern negative.

The models with random effects ((4), Tab. 10).

Interpretation of this model should not be based on the R-sq, since in a regression assessed by GLS it is no longer an adequate measure of goodness of fit. The significance of the regression as a whole in shown by a high value of Wald statistic - Wald chi2(6) $=28384.78$.

Regressors should be uncorrelated with the unobserved random effects. Otherwise, the evaluation model will be untenable.

Compared with the regression model with fixed effects, the relationship between the number of employees and other variables remained unchanged. The coefficients have not changed.

Thus, two basic regressions were evaluation: regression with fixed effects and individual regression with random individual effects. Now it is required to choose one model that is the most adequate to our data. This comparison is carried out on the estimated models using a Hausman test.

The test verified the following basic hypothesis:

$$
\mathrm{H}_{0}: \operatorname{corr}\left(\mathrm{u}_{\mathrm{i}}, \mathrm{X}_{\mathrm{u}}\right)=0
$$

Or $u_{i}$ - may be considered as random effects; when alternative 


$$
\mathrm{H}_{\mathrm{A}}: \operatorname{corr}\left(\mathrm{a}_{\mathrm{i}}, \mathrm{X}_{\mathrm{u}}\right) \neq 0
$$

$\mathrm{u}_{\mathrm{i}}-$ should be considered as deterministic effects.

This test is built on the difference between the two estimates: $\hat{q}=\widehat{b_{F E}}-\widehat{b_{R E}}$, where $\widehat{b_{F E}}-$ estimate obtained for the model with fixed effects (consistent in the case of primary and alternative hypothesis), $\widehat{\mathrm{b}_{\mathrm{RE}}}$ - evaluation obtained for the random effects model (consistent only with the basic hypothesis). The hypotheses are tested using the statistic:

$$
m=\hat{q}\left(v^{-1}(\hat{q})\right) \hat{q}
$$

Where $v(\hat{q})=V\left(\widehat{b_{F E}}\right)-v\left(\widehat{b_{R E}}\right)$, and if $H_{0}$ is true, then $m \sim X_{K}^{2}$.

The results of the Hausman test (FE vs RE) are presented in Table 7. Since the p-value $<0.01$, the basic hypothesis is rejected.

The results lead to the conclusion, that the model with fixed individual effects should be applied. This should be expected, since the study selected the specific companies with their composition being virtually unchanged from year to year.

Table 7. Hausman test \#1

\begin{tabular}{|l|c|c|c|c|}
\hline & $\begin{array}{c}\text { (b) } \\
\text { FE (2) }\end{array}$ & $\begin{array}{c}\text { (B) } \\
\text { RE (4) }\end{array}$ & $\begin{array}{c}\text { (b-B) } \\
\text { Difference }\end{array}$ & $\begin{array}{c}\text { sqrt(diag(V_b-V_B)) } \\
\text { S.E. }\end{array}$ \\
\hline Age of company & 23,110 & 22,599 & 0,510 & 0,340 \\
\hline $\begin{array}{l}\text { Localization } \\
\text { externalities }\end{array}$ & 1361,990 & 1314,680 & 47,310 & 9,170 \\
\hline Revenue & 0,000 & 0,000 & 0,000 & 0,000 \\
\hline Region & $-696,360$ & $-700,360$ & 4,001 & 1,720 \\
\hline Sector & 675,360 & 668,850 & 6,510 & 1,590 \\
\hline$\chi^{2}(4)$ & \multicolumn{3}{|c|}{37,62} \\
\hline prob $>\chi^{2}$ & \multicolumn{3}{|c|}{0.00} \\
\hline
\end{tabular}

Note that in most cases the number of employees depends on the agglomeration effect (localization affects positively, urbanization - negative), region and industry. The larger the region and its population, respectively, and the number of its workers, the greater the impact of agglomeration effects in the region. Increasing age has a positive effect on the number of employees in the company: with an increase in the age of 1 year, the number of employees on average and ceteris paribus increased by 21 people. There is a significant direct positive correlation in the number of employees and the company's revenue, but the value of the coefficient approaches zero and therefore the impact of this factor is too small.

\section{Non-linear model}

As the square of age is added (variable is significant at the $1 \%$ level), there is a negative effect of this variable, i.e. after reaching a certain age of the company the number of employees begins to decline (possibly related to the cycles of the company). The results are reflected in Table 2, where (5) model considers no the panel structure; model (6) is based on fixed effects; model (7) - on random effects.

Semilogarithmic model Iny $=\beta_{0}+\beta_{1} x=\varepsilon$ allows determining the growth pace in the number of the parameters studied. 
The dependent variable - number of employees logarithm. The results are reflected in Table 2 , where (8) is the model not taking the panel structure into account; model (9) - based on fixed effects; model (10) - on random effects.

Table 8. Hausman test \#2

\begin{tabular}{|l|c|c|c|c|}
\hline & $\begin{array}{c}\text { (b) } \\
\text { FE (9) }\end{array}$ & $\begin{array}{c}\text { (B) } \\
\text { RE (10) }\end{array}$ & $\begin{array}{c}\text { (b-B) } \\
\text { Difference }\end{array}$ & $\begin{array}{c}\text { sqrt(diag(V_b-V_B)) } \\
\text { S.E. }\end{array}$ \\
\hline Age of company & 0,010 & 0,010 & $-0,000$ & 0,000 \\
\hline $\begin{array}{l}\text { Localization } \\
\text { externalities }\end{array}$ & $-0,002$ & $-0,002$ & $-0,000059$ & 0,000 \\
\hline Revenue & 0,000 & 0,000 & $-0,000$ & 0,000 \\
\hline Region & $-0,070$ & $-0,070$ & 0,000 & 0,000 \\
\hline Sector & $-0,040$ & $-0,040$ & 0,001 & 0,000 \\
\hline$\chi^{2}(4)$ & \multicolumn{5}{|c|}{$0.00,78$} \\
\hline prob $>\chi^{2}$ & \multicolumn{5}{|c|}{0.00} \\
\hline
\end{tabular}

The results of Hausman test (FE vs RE) are presented in Table 8. Since the $p$-value $<0.01$, the basic hypothesis is rejected.

The results suggest also that using the model with fixed individual effects is appropriate.

Interpretation: increase in the age of 1 year, the growth rate of the number of employees increased by $1 \%$ [as the factor. $=0.0105 \Rightarrow$ must be multiplied by 100 and rounded to give 1 percent])

To choose the best model (linear or nonlinear) the Akaike information criterion (AIC) and Schwarz (BIC) will be used. The lower the value, the better.

Table 9. Comparison of the estimated binary models

\begin{tabular}{|c|c|c|c|}
\hline Criteria & (2) & (6) & (9) \\
\hline Akaike criterion (AIC) & 504441,2 & 504901 & 75611,81 \\
\hline Schwarz criterion (BIC) & 504488,9 & 504956,7 & 75651,59 \\
\hline
\end{tabular}


Table 10. Regression analysis

\begin{tabular}{|c|c|c|c|c|c|c|c|c|c|c|}
\hline & PR & $\mathrm{FE}$ & $\mathrm{FE}$ & RE & PR & FE & RE & Iny & $\mathrm{FE}$ & RE \\
\hline & (1) & (2) & (3) & (4) & (5) & (6) & (7) & (8) & (9) & (10) \\
\hline $\begin{array}{l}\text { Age of the } \\
\text { company }\end{array}$ & $\begin{array}{c}21,280 * * \\
(9,889)\end{array}$ & $\begin{array}{c}23,107^{* *} \\
(9,880)\end{array}$ & $\begin{array}{c}57,051^{* * *} \\
(9,997)\end{array}$ & $\begin{array}{c}22,599 * * \\
(9,883)\end{array}$ & $\begin{array}{c}659,632^{* * *} \\
(38,076)\end{array}$ & $\begin{array}{c}697,911^{* * *} \\
(38,731)\end{array}$ & $\begin{array}{c}659,632^{* * *} \\
(38,076)\end{array}$ & $\begin{array}{c}0,011^{* * *} \\
(0,000)\end{array}$ & $\begin{array}{c}0,011^{* * *} \\
(0,000)\end{array}$ & $\begin{array}{c}0,011^{* * *} \\
(0,000)\end{array}$ \\
\hline Squared age & & & & & $\begin{array}{c}-5,476 * * * \\
(0,333)\end{array}$ & $\begin{array}{c}-5,782^{* * *} \\
(0,338)\end{array}$ & $\begin{array}{c}-5,476372 * * * \\
(0,333)\end{array}$ & & & \\
\hline $\begin{array}{l}\text { Localization } \\
\text { externalities }\end{array}$ & $\begin{array}{c}1191,954 * * * \\
(46,152)\end{array}$ & $\begin{array}{c}1361,985^{* * *} \\
(49,178)\end{array}$ & & $\begin{array}{c}1314,675^{* * * *} \\
(48,357)\end{array}$ & & & & & & \\
\hline $\begin{array}{l}\text { Urbanization } \\
\text { externalities }\end{array}$ & & & $\begin{array}{c}-7,068 * * \\
(3,203)\end{array}$ & & $\begin{array}{c}-7,933 * * \\
(3,183)\end{array}$ & $\begin{array}{c}-6,962317^{* *} \\
(3,181)\end{array}$ & $\begin{array}{c}-7,933^{* *} \\
(3,183)\end{array}$ & $\begin{array}{c}-0,002 * * * \\
(0,000)\end{array}$ & $\begin{array}{c}-0,002 * * * \\
(0,000)\end{array}$ & $\begin{array}{c}-0,002^{* * *} \\
(0,000)\end{array}$ \\
\hline Revenue & $\begin{array}{c}0,000 * * * \\
(0,000)\end{array}$ & $\begin{array}{c}0,000 * * * \\
(0,000)\end{array}$ & $\begin{array}{c}0,000 * * * \\
(0,000)\end{array}$ & $\begin{array}{c}0,000 * * * \\
(0,000)\end{array}$ & $\begin{array}{c}0,000 * * * \\
(0,000)\end{array}$ & $\begin{array}{c}0,000 * * * \\
(0,000)\end{array}$ & $\begin{array}{c}0,000 * * * \\
(0,000)\end{array}$ & $\begin{array}{c}0,000 * * * \\
(0,000)\end{array}$ & $\begin{array}{c}0,000 * * * \\
(0,000)\end{array}$ & $\begin{array}{c}0,000 * * * \\
(0,000)\end{array}$ \\
\hline Region & $\begin{array}{c}-709,358 * * * \\
(64,808)\end{array}$ & $\begin{array}{c}-696,364 * * * \\
(64,654)\end{array}$ & $\begin{array}{c}-743,243^{* * *} \\
(66,188)\end{array}$ & $\begin{array}{c}-700,3644^{* * *} \\
(64,685)\end{array}$ & $\begin{array}{c}-431,146^{* * *} \\
(68,217)\end{array}$ & $\begin{array}{c}-436,447^{* * *} \\
(68,133)\end{array}$ & $\begin{array}{c}-431,146 * * * \\
(68,217)\end{array}$ & $\begin{array}{c}-0,069 * * * \\
(0,0025)\end{array}$ & $\begin{array}{c}-0,069 * * * \\
(0,003)\end{array}$ & $\begin{array}{c}-0,069^{* * *} \\
(0,003)\end{array}$ \\
\hline Sector & $\begin{array}{c}652,843^{* * *} \\
(30,941)\end{array}$ & $\begin{array}{c}675,356 * * * \\
(30,975)\end{array}$ & $\begin{array}{c}404,179 * * * \\
(31,250)\end{array}$ & $\begin{array}{c}668,848 * * * \\
(30,961)\end{array}$ & $\begin{array}{c}338,938 * * * \\
(31,369)\end{array}$ & $\begin{array}{c}326,262 * * * \\
(31,368)\end{array}$ & $\begin{array}{c}338,938 * * * \\
(31,369)\end{array}$ & $\begin{array}{c}-0,039 * * * \\
(0,001)\end{array}$ & $\begin{array}{c}-0,038^{* * *} \\
(0,001)\end{array}$ & $\begin{array}{c}-0,039 * * * \\
(0,00119)\end{array}$ \\
\hline Constant & $\begin{array}{c}-23412,920 * * * \\
(964,782)\end{array}$ & $\begin{array}{c}-25468,620 * * * \\
(986,05)\end{array}$ & $\begin{array}{c}-8505,565^{* * *} \\
(786,108)\end{array}$ & $\begin{array}{c}-24713,070 * * * \\
(1108,859) \\
\end{array}$ & $\begin{array}{c}-12449,870 * * * \\
(816,446)\end{array}$ & $\begin{array}{c}-12593,100 * * * \\
(816,419) \\
\end{array}$ & $\begin{array}{c}-12449,870 * * * \\
(816,446)\end{array}$ & $\begin{array}{c}8,572^{* * *} \\
(0,030)\end{array}$ & $\begin{array}{c}8,570 * * * \\
(0,030)\end{array}$ & $\begin{array}{c}8,57181^{* * * *} \\
(0,030)\end{array}$ \\
\hline $\begin{array}{l}\text { Number of } \\
\text { observations }\end{array}$ & 21102 & 21102 & 21102 & 21102 & 21102 & 21102 & 21102 & 21102 & 21102 & 21102 \\
\hline Prob>chi2 & 0,000 & 0,000 & 0,000 & 0,000 & 0,000 & 0,000 & 0,000 & 0,000 & 0,000 & 0,000 \\
\hline Adj R-squared & 0,687 & & & & 0,681 & & & 0,489 & & \\
\hline $\begin{array}{l}\text { R-squared } \\
\text { Within }\end{array}$ & & 0,676 & 0,676 & 0,687 & & 0,681 & 0,681 & & 0,483 & 0,483 \\
\hline $\begin{array}{l}\text { R-squared } \\
\text { Between }\end{array}$ & & 0,968 & 0,910 & 0,968 & & 0,884 & 0,886 & & 0,965 & 0,966 \\
\hline
\end{tabular}


As we can see in Table 9, the smallest value of the criteria is observed for the first model and therefore a linear model is the best one.

\section{Conclusion}

In this paper we analyze the spatial concentration of industry in Germany. For this reason, it assessed the impact of agglomeration effect on the number of employees. The first results from the evaluation of the linear model show a positive influence of the effect of localization (localization externalities), while the effect of urbanization (urbanization externalities) demonstrated a negative impact. It should also be noted that the number of employees is also affected by the region where the company is located and the industry in which the company operates. The larger the region and its population, respectively, the larger the number of its workers and the greater impact of agglomeration effects in the region. Increasing age has a positive effect on the company's number of employees in the company: with an increase in the age of 1 year, the number of employees on average and ceteris paribus increased by 21 people. There is a significant direct positive correlation in number of employees from the company's revenue, however the value of the coefficient approaches zero and therefore the impact of this factor is too small.

In addition to the linear model of a preliminary assessment and non-linear model - a model with the addition of the square of the age and model with the natural logarithm of the number of employees have been constructed. However, using the information criteria of Akaike (AIC) and Schwarz (BIC) we found that non-linear models are not the best. Therefore, this question remains open for further study.

During the research it was not confirmed that the company, located in some region of the country and depending on a certain kind of natural resources, will have a high level of spatial concentration and vice versa. This issue is subject to further study. However, the second hypothesis was confirmed by the econometric studies by constructing a linear model: the company with the central office (headquarters - apartment) will have a greater measure of spatial concentration in the major regions and the cities than in small villages, since the head offices are usually located in big cities.

In addition to the above arguments, further prospects of studies can include evaluation of the spatial concentration of industry in the other European countries. Since this paper presents an analysis of the NUTS 1 level regions, a more detailed analysis at the level of NUTS 2 and NUTS 3 may be conducted in future. Also, for more detailed analysis it is possible to add the publicly available "number of employees" dependent variable dataand to perform surveys in the companies in order to obtain more specific information, such as "wage rate", "actual number of hours worked" and other data.

\section{References}

Anastassova L., 2006. Productivity differences and agglomeration across districts of Great Britain. CERGE-El Working Paper, vol. 289.

Arbeitsmarkt https://www.destatis.de/DE/ZahlenFakten/Indikatoren/LangeReihen/Arbeitsmarkt/ Irerw013.html [1 May 2016]. 
Artis M., Curran D., Sensier M. 2011. Investigating agglomeration economies in a panel of European cities and regions. SERC Discussion Papers, SERCDP0078. Spatial Economics Research Centre, London: London School of Economics and Political Science.

Baldwin J., Brown M., Rigby D., 2010. Agglomeration economies: micro data panel estimates from Canadian manufacturing. Journal of Regional Science, vol. 50(5), pp. 915-934.

Blien U., Suedekum J., Wolf K., 2006. Local employment growth in West Germany: A dynamic panel approach. Labour Economics, vol. 13(4), pp. 445-458.

Campante F. R., Do Q. A., 2009. Centered Index of Spatial Concentration: Expected Influence Approach and Application to Population and Capital Cities, http://citeseerx.ist.psu.edu/viewdoc/ summary?doi=10.1.1.184.9110 [1 September 2016].

Ciccone A., 2002. Agglomeration Effects in Europe. European Economic Review, vol. 46 (2), pp. 213-227.

Ciccone A., Hall R., 1996. Productivity and the Density of Economic Activity. American Economic Review, vol. 86, pp. 54-70.

Combes P., 2000. Marshall-Arrow-Romer Externalities and City Growth. Journal of Urban Economics. vol. 47, pp. 329-355.

Davi M., Lopez-Bazo E., Barbaccia I., 2009. Measurement of Agglomeration and Spatial Effects. DE Statis: Statistisches Bundesamt, https://www.destatis.de/DE/Startseite.html [1 September 2016].

Duranton G., Overman H., 2005. Testing for Localization Using MicroGeographic Data. Review of Economic Studies, vol. 72, pp. 1077-1106.

Eckey H. F., Kosfeld R., Muraro N., 2009. Effects of population development on the economic level of the regions in Germany. Jahrbuch für Wirtschaftswissenschaften/Review of Economics, pp. 204-226.

Ellison G., Glaeser E., 1994. Geographical Concentration in U.S. Manufacturing Industries: A Dartboard Approach. Journal of Political Economy, vol. 105(5), pp. 889-927.

Ellison G., Glaeser E. L., 1999. The geographic concentration of industry: does natural advantage explain agglomeration? The American Economic Review, vol. 89(2), pp. 311-316.

Fafchamps M., 2004. Manufacturing Growth and Agglomeration Effects. CSAE Working Paper Series from Centre for the Study of African Economies, University of Oxford, vol. 204(33).

Fafchamps M., El Hamine S., 2004. Firm Productivity, Wages, and Agglomeration Effects. CSAE Universityof Oxford.

Fuchs M., 2011. The determinants of local employment dynamics in Western Germany. Empirical Economics, vol. 40(1), pp. 177-203.

Furtuna TF, Reveiu A., Dardala M., Kanala R., 2013. Analysing the Spatial Concentration of Economic Activities: A Case Study of Energy Industry in Romania. Economic Computation And Economic Cybernetics Studies And Research, vol. 47(4).

Gallo L., Dall'Erba S., 2007. The impact of EU regional support on growth and employment. Czech Journal of Economics and Finance, vol. 57(7), pp. 325-340.

Gao T., 2004. Regional industrial growth: evidence from Chinese industries. Regional Science and Urban Economics, vol. 34(1), pp. 101-124.

Glaeser E. L., Kahn M. E., 2010. The greenness of cities: carbon dioxide emissions and urban development. Journal of urban economics, vol. 67(3), pp. 404-418.

Glaeser E., Kallal H., Scheinkman J., Shleifer A., 1992. Growth in cities. Journal of Political Economy. vol. 100(6), pp. 1126-1152.

Gordon I. R., McCann P., 2000. Industrial clusters: complexes, agglomeration and/or social networks? Urban studies, vol. 37(3), pp. 513-532.

Jacobs J., 1969. The Economy of Cities, New York: Random House. 
Jaffe A. B., Trajtenberg M., Henderson R., 1993. Geographic localization of knowledge spillovers as evidenced by patent citations. The Quarterly journal of Economics, pp. 577-598.

Kominers S. D., 2008. Measuring agglomeration. Harvard Urban and Social Economics Seminar http:// www.scottkom.com/articles/measure_agglomeration.pdf [1 September 2016].

Krugman P., 1991. Geography and trade. London: The MIT Press.

Kutsenko E., 2012. Path Dependence in Spatial Distribution of Economic Activity: Bad News for Empiric Research of Agglomeration Effects. Institute for Statistical Studies and Economics of Knowledge, Moscow: National Research University "Higher School of Economics".

Marshall A., 1890. Principles of Economics. London: Macmillan.

Mori T., Nishikimi K., Smith T. A, 2005. Divergence Statistic for Industrial Localization. The Review of Economics and Statistics, MIT Press, vol. 87(4), pp. 635-651.

Palan N., 2010. Measurement of Specialization The Choice of Indices. FIW working paper, 2010, vol. 62.

Rosenfeld M. T. W., Franz P., Heimpold G., 2005. The Pattern of Spatially Concentrated Industries in East Germany-A Contribution to the Discussion on Economic" Clusters" [in:] Proceedings of the International Conference on Regional Growth Agendas, Aalborg, Denmark.

Rysman M., Greenstein S., 2005. Testing for Agglomeration and Dispersion. Economics Letters, vol. 86, pp. 405-411.

Statistisches Jahrbuch Deutschland und Internationales. 2012, Statistisches Bundesamt https:// www.destatis.de/DE/Publikationen/StatistischesJahrbuch/StatistischesJahrbuch2012.pdf? blob=publicationFile [1 September 2016].

Vorobyev P., Kislyak N., Davidson N., 2014. Industrial diversity and concentration in Russian cities: the impact on economic efficiency. Ural Federal University. Economics and management, vol. 6, pp. 4-18.

Wennberg K., Lindqvist G., 2010. The effect of clusters on the survival and performance of new firms. Small Business Economics, vol. 34(3), pp. 221-241.

Weterings A., Marsili O., 2015. Spatial concentration of industries and new firm exits: Does this relationship differ between exits by closure and by M\&A? Regional Studies, vol. 49(1), pp. 44-58.

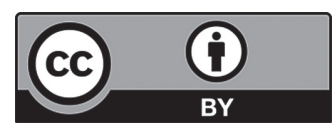

